\title{
LLLT enhance cyclophosphamide induced TRPM2 channel activation in human colon cancer cells
}

\author{
Guler $\mathrm{Y}^{1}$, Ovey $\mathrm{IS}^{2}$ \\ Alanya Alaaddin Keykubat University Medical Faculty Education and Research Hospital, \\ Department of General Surgery, Alanya, Antalya, Turkey. yilmaz.guler@alanya.edu.tr
}

\begin{abstract}
AIM: Transient receptor potential (TRP) channels expression is enhanced significantly in colon cancer cells and Low Lever Laser Treatment (LLLT), is known to have effects and is used clinically in the treatment ofmany diseases, including colon cancer. We aimed to reveal the effects of (LLLT) on apoptosis of colon cancer and on the efficacy of cyclophosphamide via Transient receptor potential melastatin 2 (TRPM2) channels.

METHOD: Human colon cancer cells (Caco-2) were cultured and cells were divided into seven main groups. Cells were incubated with cyclophosphamide, TRPM2 channel inhibitor, stimulator and low level laser exposure separately and together. The effects of cyclophosphamide and low level laser were investigated on apoptosis.

RESULTS: It was found that the levels of apoptosis in cyclophosphamide group were significantly increased in cancer cells compared to the control group. TRPM2 channel stimulator administration resulted in significantly increased apoptosis levels compared to the control group, in cyclophosphamide + low level laser group the apoptosis level was significantly increased compared to the cyclophosphamide-only group.

CONCLUSIONS: It has been shown that apoptotic effects of cyclophosphamide on colon cancer cells were directly related to TRPM2 channels, low level laser increased apoptosis in colon cancer cells through TRPM2 channels and induced apoptotic effect of cyclophosphamide (Fig. 5, Ref. 26). Text in PDF www.elis.sk. KEY WORDS: cyclophosphamide, low level laser, TRPM2, colon cancer.
\end{abstract}

\section{Introduction}

Colorectal cancer (CRC) is the third most common cancer after prostate cancer in men and the second most common cancer in women following breast cancer, with approximately 1.36 million new cases reported each year (1). Chemotherapy has been widely used in the treatment of CRC and significant advances in treatment were achieved in CRC owing to the improvements in chemotherapy management in recent years. Cyclophosphamide (CP) is widely used in the treatment of numerous malignant diseases and in the treatment of colon cancer. CP stimulates apoptosis as the result of interaction with cellular macromolecules such as: proteins, membrane lipids, RNA and DNA (2). In animal model studies performed during the last decade, $\mathrm{CP}$, which has been suggested as a salvage therapy in low doses to prevent tumour angiogenesis in end-stage cancer patients, has also been shown to have an immunomodulatory effect (3).

${ }^{1}$ Alanya Alaaddin Keykubat University Medical Faculty, Department of General Surgery, Alanya, Antalya, Turkey, and ${ }^{2}$ Alanya Alaaddin Keykubat University Medical Faculty, Department of Physiology, Alanya, Antalya, Turkey

Address for correspondence: Y. Guler, Alanya Alaaddin Keykubat University Medical Faculty Education and Research Hospital, Department of General Surgery Postal Code: 07400 Alanya, Antalya, Turkey.

Phone: +902425134841, Fax: +902425134840
Transient receptor potential (TRP) channels have six subtypes in mammals: TRPC (canonical), TRPV (vanilloid), TRPM (melastatin), TRPP (Polycystin), TRPML (mucolipin) and TRPA (ankyrin). TRP channels respond well to oxidative stress mediators such as: reactive oxygen species (ROS), reactive nitrogen species (RNS) and other electrophiles. The transient receptor potential melastatin-2 (TRPM2) channel, which is the first identified ROS sensitive channel, is activated by hydrogen peroxide $\left(\mathrm{H}_{2} \mathrm{O} 2\right)$ and is the mediator of numerous cellular responses including cell death and chemokine production (4). It has been reported that TRPM2 channels have crucial effects on migration and cell death in tumour cells and immune system cells and its expression is enhanced significantly in adenocarcinomas such as: breast cancer, head and neck, bladder, liver, pancreas, colon and lung adenocarcinomas $(5,6)$.

Low Level Laser Therapy (LLLT), also known as photobiomodulation, acts by penetration of infrared rays into human tissues with wavelengths specific for therapeutic purposes and visible infrared rays with low energy (7). The mechanism of action of LLLT is based on the direct biostimulatory effect that gives light energy to cells. Cellular photoreceptors absorb light and then transfer to mitochondria for ATP production. As the result of increased vasodilatation with ATP synthesis, oxygen usage increases and cell mitosis is stimulated by nucleic acids and cytoplasmic enzyme activities boost (8). LLLT is used clinically in the treatment of several disorders and there are studies examining its efficacy in many diseases including colon cancer (9). 
In this study, by applying LLLT and CP on colon cancer cell culture, we aimed to reveal the effects of LLLT on apoptosis of colon cancer and on the efficacy of CP via TRPM2 channels and the role of TRPM2 channels in this process.

\section{Materials and methods}

\section{Cell culture and Low-Level Laser Application}

Human Colon Cancer Cell line (Caco-2) was maintained from the Culture Collection of Animal Cells, Foot and Mouth Disease (ŞAP) Institute, Ankara, Turkey. Caco-2 cells were cultured in Dulbecco's modified Eagle's medium (DMEM). Mediums were used for cell cultures containing $10 \%$ foetal bovine serum (FBS) (Fisher Scientific), and $1 \%$ pen./strep. antibiotic combination (Thermo-Fischer). Caco-2 cells were evenly distributed as $1 \times 10^{6}$ cells in each of the 8-10 flasks (filter cap, sterile, $5 \mathrm{ml}, 25 \mathrm{~cm}^{2}$ ). A humidified incubator was used to incubate them at $37^{\circ} \mathrm{C}$ at $5 \%$ $\mathrm{CO}_{2}$. After cells have reached 75-80\% confluence, cells were incubated with $\mathrm{CP}$ as described in the groups section. Following the CP incubation, detached ( $0.25 \%$ Trypsin-EDTA $)$ and washed cells were put into sterile $9.6 \mathrm{~cm}^{2}$ plate wells quickly $\left(2 \times 10^{6}\right.$ cells for per well) and laser applications (Laspot GD-P-1 Pain Laser Therapy Device, U.S.A ) were performed at $808 \mathrm{~nm}$ wavelengths to the cells $\left(30 \mathrm{Joule} / \mathrm{cm}^{2}\right)$ as covering the entire well. Cells were examined daily for evidence of contamination. After laser application, the cells were split into the sterile falcon tubes for analyses.

\section{Reagents/Dyes}

Caspase 3 (AC-DEVD-AMC) and Caspase 9 (AC-LEHDAMC) substrates were obtained from Enzo (Lausen, Switzerland). APOPercentage assays with releasing buffer were obtained from Biocolor (Belfast, Northern Ireland). A mitochondrial stain 5,50, 6,60-tetrachloro-1,10,3,30-tetraethylbenzimidazolyl carbocyanine iodide (JC-1) and Probenecid were obtained from Santa Cruz (Dallas, Texas, USA). Pluronic $\AA$ F-127 was obtained from Biovision(San Francisco, USA). Dihydrorhodamine-123 (DHR 123), was obtained from Sigma Aldrich (St. Louis, MO), Fura-2 AM calcium florescent dye was obtained from Calbiochem (Darmstadt, Germany).

\section{Groups}

The study was planned as 7 main groups below,

Group 1 (Control): None of the study drugs were used and colon cancer cells were preserved in a flask with the same cell culture condition.

Group 2 (CP): Cells in the group were incubated with CP $(50 \mathrm{mM})$ for $24 \mathrm{hrs}(10)$.

Group $3(\mathrm{CP}+\mathrm{ACA})$ : Cells in the group were incubated with $\mathrm{CP}$ $(50 \mathrm{mM})$ for $24 \mathrm{hrs}$ and then incubated with Antranilic acid (TRPM2 channel blocker) (ACA, $0.1 \mathrm{mM}, 30 \mathrm{~min}$ ).

Group 4 (CP+LLLT): Cells in the group were incubated with CP $(50 \mathrm{mM})$ for $24 \mathrm{hrs}$ and then exposed to laser beams at $808 \mathrm{~nm}$ $\left(30 \mathrm{~J} / \mathrm{cm}^{2}\right)$

Group $5(\mathrm{CP}+\mathrm{LLLT}+\mathrm{ACA})$ : Cells in the group were incubated with $\mathrm{CP}(50 \mathrm{mM})$ for $24 \mathrm{hrs}$ and then exposed to laser beams at $808 \mathrm{~nm}\left(30 \mathrm{~J} / \mathrm{cm}^{2}\right)$ and then incubated with Antranilic acid (ACA, $0.1 \mathrm{mM}, 30 \mathrm{~min}$ ).

Group 6 (LLLT): Cells in the group were exposed to laser beams at $808 \mathrm{~nm}\left(30 \mathrm{~J} / \mathrm{cm}^{2}\right)$

Group 7 (LLLT+ACA): Cells in the group were exposed to laser beams at $808 \mathrm{~nm}\left(30 \mathrm{~J} / \mathrm{cm}^{2}\right)$ and then incubated with Antranilic acid (ACA, $0.1 \mathrm{mM}, 30 \mathrm{~min}$ ).

In ACA incubated groups, Caco- 2 cells were also blocked by TRPM2 blocker ACA ( $0.1 \mathrm{mM}, 30 \mathrm{~min})$ before a related analysis in the existence of $1.2 \mathrm{mM}$ calcium in extracellular environment. For all the experiments (except for calcium signalling), the cells were further treated with cumene hydroperoxide $(\mathrm{Cpx}, 0.1 \mathrm{mM}$, $10 \mathrm{~min}$ ) for activation of TRPM2 channel before a related analysis. During calcium signalling analysis (Fura-2 AM), cells were stimulated on 20th cycles with $0.1 \mathrm{mM} \mathrm{Cpx}$ in the existence of $1.2 \mathrm{mM}$ calcium and calcium free buffer in extracellular environment.

\section{Measurements of intracellular calcium concentration}

Fluorescent Fura-2 AM (acetoxymethyl ester) dye was used for measuring the intracellular calcium level in Caco- 2 cells. The cells were incubated with HEPES-buffered saline [HBS; $5 \mathrm{mM} \mathrm{KCl}$, $145 \mathrm{mM} \mathrm{NaCl}, 10 \mathrm{mM}$ D-glucose, $1 \mathrm{mM} \mathrm{MgCl}, 1,2 \mathrm{mM} \mathrm{CaCl}$, $10 \mathrm{mM}$ HEPES and $0.1 \%(\mathrm{w} / \mathrm{v})$ bovine serum albumin (BSA); $\mathrm{pH}$ 7.4] containing $5 \mu \mathrm{M}$ Fura- 2 AM and $0.05 \%$ (w/v) Pluronic F-127 for $60 \mathrm{~min}$ at $37^{\circ} \mathrm{C}$ in the dark. The loaded cells were washed twice with HBS and covered with $1 \mathrm{ml}$ of HBS supplemented with $2.5 \mathrm{mM}$ probenecid for at least $20 \mathrm{~min}$ at $37^{\circ} \mathrm{C}$ in the dark to allow for Fura-2 AM de-esterification. Fluorescence intensity at $510 \mathrm{~nm}$ (emission) was determined in individual wells using a plate reader equipped with an automated injection system (SynergyTM H1, Biotek, USA) at alternating excitation wavelengths of 340 and $380 \mathrm{~nm}$ every $3 \mathrm{~s}$ for 50 acquisition cycles. During the measurement of intracellular calcium signalling, TRPM2 channels were stimulated by automatic injector with cumene hydroperoxide (Cpx, $0.1 \mathrm{mM})$ on 20th cycle. Measurement of $\left[\mathrm{Ca}^{2+}\right] \mathrm{i}$ including staining process modification was performed according to the method of Martinez et al (11).

\section{Intracellular ROS production measurement}

Dihydrorhodamine 123 (DHR 123) is a non-charged and nonfluorescent dye, which easily crosses the cell membrane. DHR123 is oxidized to cationic rhodamine 123 (Rh 123) in Caco-2 cells, which is situated in the mitochondria and indicates with green fluorescence. Caco- 2 cells $\left(10^{6}\right.$ cell $/ \mathrm{ml}$ for per group) were incubated with $20 \mu \mathrm{m}$ DHR 123 as florescent oxidant dye at $37{ }^{\circ} \mathrm{C}$ for 25 min(12). Synergy ${ }^{\mathrm{TM}} \mathrm{H} 1$ automatic microplate reader device was used for determining Rh 123 fluorescent density. The measurements were performed at $488 \mathrm{~nm}$ (excitation) and $543 \mathrm{~nm}$ (emission) wavelengths. We presented the data as a fold increase over the level before treatment.

\section{Apoptosis assay}

The APOPercentage ${ }^{\mathrm{TM}}$ cell apoptosis assay was used for the detection and quantity measurement of apoptosis. The APOPer- 

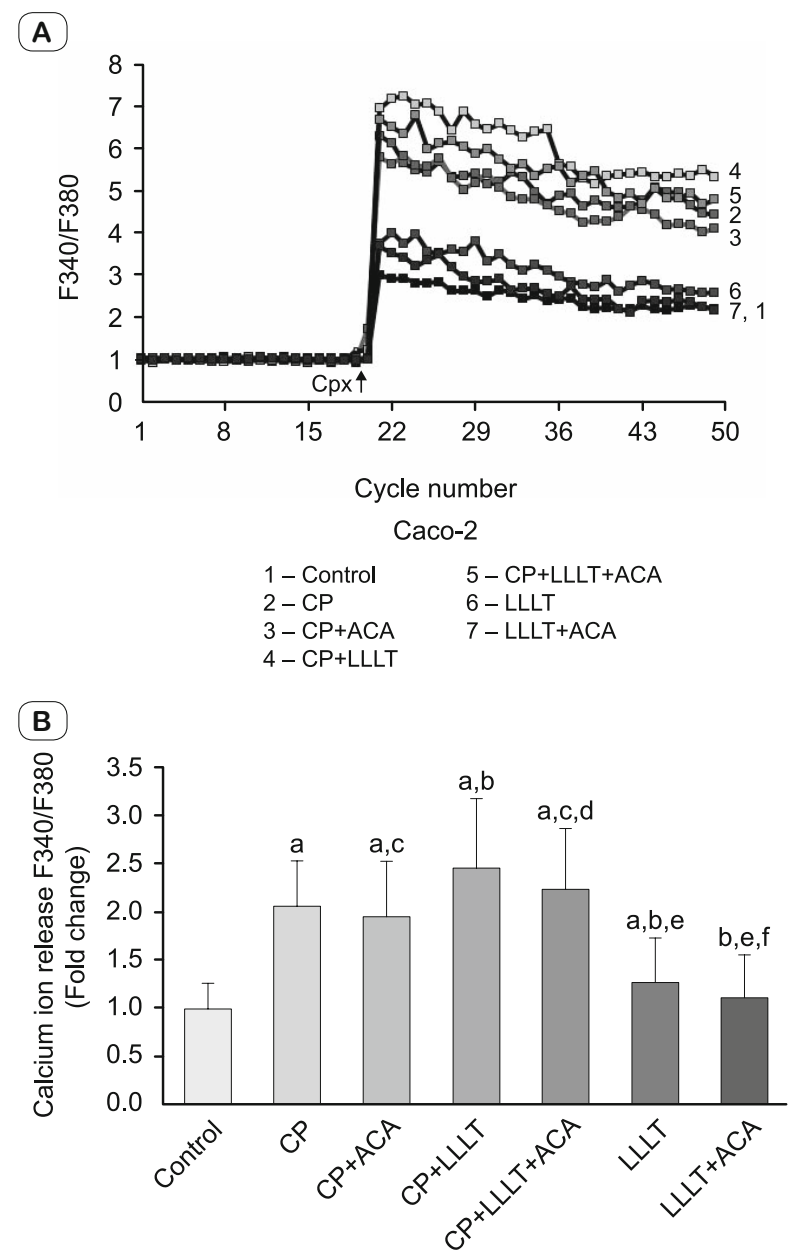

Fig. 1. Effect of Cyclophosphamide (CP, $50 \mathrm{mM}, 24 \mathrm{hrs})$ and LLLT $\left(808 \mathrm{~nm}, 30 \mathrm{Joule} / \mathrm{cm}^{2}\right)$ on cytosolic calcium levels in Caco-2 cells. Cells are stimulated by Cumene hyroperoxyde (Cpx, $0.1 \mathrm{mM}$ and on 20th cycle) but they were inhibited by Antranilic acid (ACA, $0.1 \mathrm{mM}$ for $30 \mathrm{~min})($ mean \pm SD and $n=3) .{ }^{\mathrm{a}} \mathrm{p}<0.001$ vs control, ${ }^{\mathrm{b}} \mathrm{p}<0.001$ and ${ }^{\mathrm{c}} \mathrm{p}<0.05$ vs CP group, ${ }^{\mathrm{d}} \mathrm{p}<0.05$ and ${ }^{\mathrm{e}} \mathrm{p}<0.001$ vs $\mathrm{CP}+$ LLLT group and ${ }^{\mathrm{f}} \mathbf{p}=\mathbf{0 . 0 5}$ vs LLLT group.

centage dye was actively bound to phosphatidyl-serine lipids and transferred into the cells and apoptotic cells were stained red. The apoptosis analyses procedure was performed according to the manufacturer instructions and Öz and Celik 2017 (12). Analysis of apoptotic cells in Caco-2 cells were performed by spectrophotometry (multiplate reader) at $550 \mathrm{~nm}$ (Synergy ${ }^{\mathrm{TM}} \mathrm{H} 1$, Biotek, USA).

\section{Mitochondrial membrane potential (JC-1) analyses}

The mitochondrial membrane potential $(1 \mu \mathrm{M})$ fluorescence dye density was measured by $485 \mathrm{~nm}$ (green) excitation wavelength and the emission wavelength of $535 \mathrm{~nm}$, the red signal at the $540 \mathrm{~nm}$ (excitation) and $590 \mathrm{~nm}$ (emission) the wavelengths (Synergy ${ }^{\mathrm{TM}}$ H1, Biotek, USA) (12). Data were presented as emission ratios (590/535). Mitochondrial membrane potential changes were quantified as the integral of the decrease in JC-1 fluorescence ratio of experimental/control.
Caspase 3 \& 9 activity assays

Caspase 9 and Caspase 3 activity evaluation methods were used as previously reported (13). Caspase 9 (AC-LEHD-AMC) and Caspase 3 (AC-DEVD-AMC) substrates segmentations were measured with Synergy ${ }^{\mathrm{TM}} \mathrm{H} 1$ microplate reader (Biotek, USA) with $360 \mathrm{~nm}$ and $460 \mathrm{~nm}$ wavelengths (excitation/emission). The measurements were evaluated as fluorescent units/mg protein and shown as fold change from the level before treatment (experimental/control).

\section{Statistical analyses}

All results were expressed as the mean \pm standard deviation (SD). Significant values in the groups were assessed with one-way ANOVA. Statistical analyses were performed using GraphPad.

Prism version 7.04 for windows (GraphPad Software, San Diego California, the USA). $\mathrm{p}<0.05$ was considered significant.

\section{Results}

Effects of CP and LLLT treatments on $\left[\mathrm{Ca}^{2+}\right]_{i}$ concentration, intracellular ROS, mitochondrial membrane depolarization (JC-1), Caspase 3 and Caspase 9 values

As the result of the application of CP and LLLT on Caco-2 separately and together, intracellular $\mathrm{Ca}^{2+}$ levels, intracellular ROS, mitochondrial depolarization, Caspase 3 and Caspase 9 levels were increased statistically significantly in the CP group. In the $\mathrm{CP}+\mathrm{ACA}(\mathrm{CP}+\mathrm{TRPM} 2$ channel inhibitor) group, intracellular $\mathrm{Ca}^{2+}$, intracellular ROS, mitochondrial depolarization, Caspase 3 and Caspase 9 levels were significantly decreased compared to the CP group $(\mathrm{p}<0.001)\left(\mathrm{p}<0.05\right.$ for intracellular $\mathrm{Ca}^{2+}$ analysis; $\mathrm{p}<0.001$ for ROS, mitochondrial depolarization, Caspase 3 and Caspase 9 levels). In the LLLT group however, intracellular $\mathrm{Ca}^{2+}$ levels, intracellular ROS, mitochondrial depolarization, Caspase 3 and Caspase 9 levels were significantly increased in cancer cells compared to the control group $(\mathrm{p}<0.001)$. In the CP

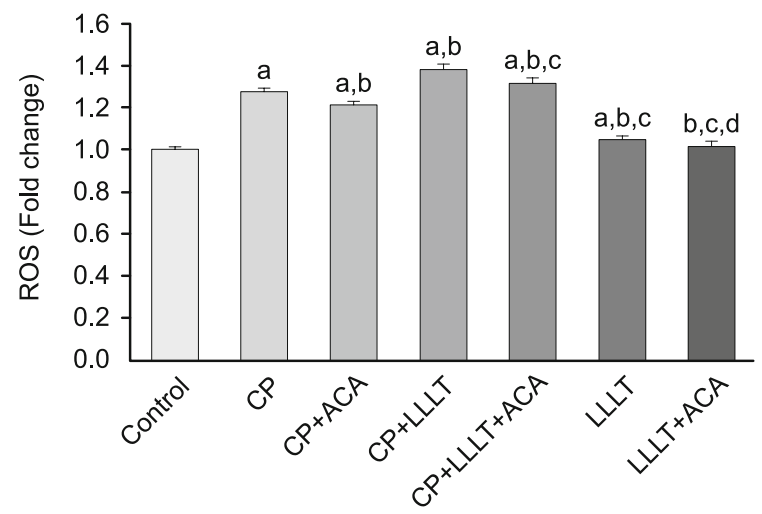

Fig. 2. The effect of Cyclophosphamide (CP, $50 \mathrm{mM}, 24 \mathrm{hrs}$ ) and LLLT $\left(808 \mathrm{~nm}, 30 \mathrm{Joule} / \mathrm{cm}^{2}\right)$ on Reactive Oxygene Species levels in the Caco2 Cells. Cells are stimulated by Cumene hydroperoxyde (Cpx, $0.1 \mathrm{mM}$ for $10 \mathrm{~min}$ ) but they were inhibited by Antranilic acid (ACA, 0.1 mM, 30 min) (mean \pm SD and $n=10) .{ }^{a} \mathbf{p}<0.001$ vs control, ${ }^{\mathrm{b}} \mathbf{p}<\mathbf{0 . 0 0 1}$ vs $\mathbf{C P}$ group, ${ }^{c} \mathbf{p}<0.001$ vs $C P+L L L T$ group and ${ }^{d} p \leq 0.001$ vs $L L L T$ group. 


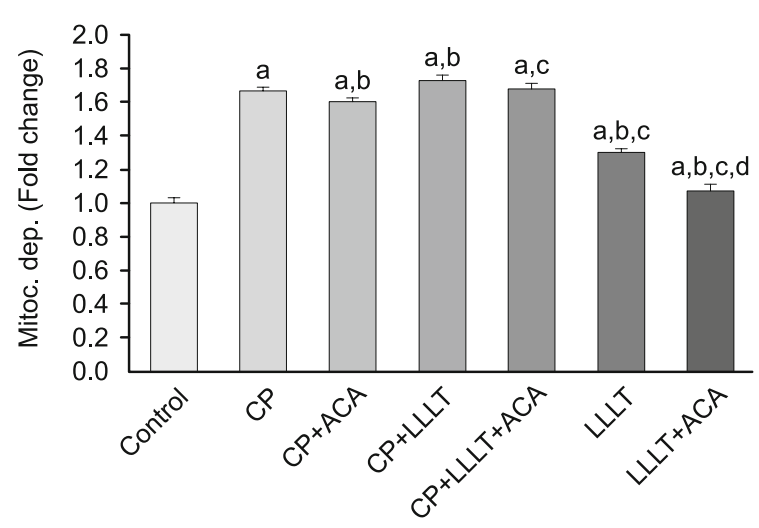

Fig. 3. The effect of Cyclophosphamide (CP, $50 \mathrm{mM}, 24 \mathrm{hrs})$ and LLLT $\left(808 \mathrm{~nm}, 30 \mathrm{Joule} / \mathrm{cm}^{2}\right)$ on mitochondrial depolarization levels in the Caco-2 Cells. Cells are stimulated by Cumene hydroperoxyde (Cpx, 0.1 $\mathrm{mM}$ for $10 \mathrm{~min}$ ) but they were inhibited by Antranilic acid (ACA, 0.1 $\mathbf{m M}, 30$ min $)($ mean \pm SD and $n=10) .{ }^{\text {a }} \mathbf{p}<0.001$ vs control, ${ }^{b} p<0.001$ vs CP group, ${ }^{\mathrm{c}} \mathrm{p}<0.001$ vs CP+LLLT group and ${ }^{\mathrm{d}} \mathrm{p}<0.001$ vs LLLT group.

+ LLLT groups, intracellular $\mathrm{Ca}^{2+}$ levels, intracellular ROS, mitochondrial depolarization, Caspase 3 and Caspase 9 levels were found to be increased significantly compared to the CP-only group ( $p<0.05$ for intracellular $\mathrm{Ca}^{2+}$ level, $\mathrm{p}<0001$ for other levels). When CP+LLLT and CP+LLLT+ACA groups were compared, a statistically significant decrease was detected in the ACA groups except Caspase 9 analysis ( $\mathrm{p}<0.05$ for intracellular $\mathrm{Ca}^{2+}$ level; $\mathrm{p}<0.001$ for caspase 3 , ROS and mitochondrial depolarization) (Figs 1, 2, 3, 4).

\section{Results of apoptosis values in Caco-2 cell line}

As the result of the application of CP and LLLT on Caco- 2 cell culture separately and together, the apoptosis level increased significantly in the CP group compared to the control group $(\mathrm{p}<0.001)$.

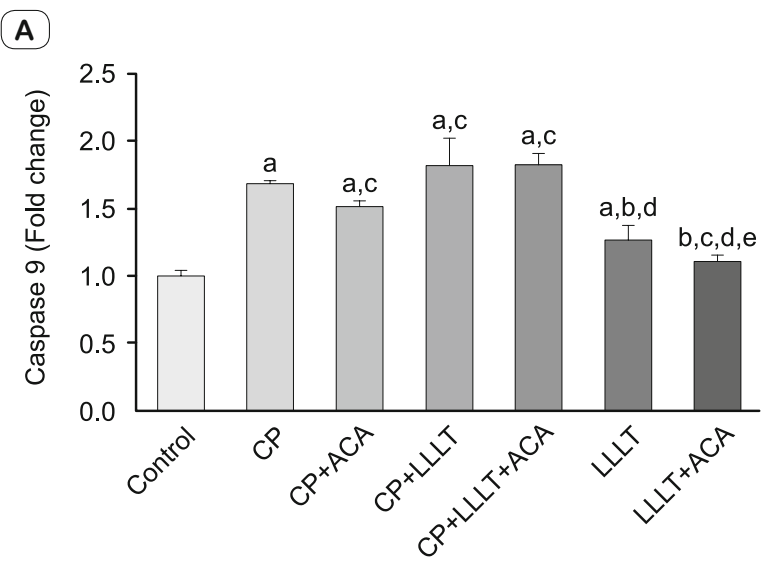

Fig. 4A. The effect of Cyclophosphamide (CP, $50 \mathrm{mM}, 24 \mathrm{hrs})$ and LLLT $(808 \mathrm{~nm}, 30$ Joule/cm2) on caspase 9 levels in the Caco-2 Cells. Cells are stimulated by Cumene hydroperoxyde (Cpx, $0.1 \mathrm{mM}$ for 10 $\mathrm{min}$ ) but they were inhibited by Antranilic acid (ACA, $0.1 \mathrm{mM}, 30 \mathrm{~min}$ ) (mean \pm SD and $n=10$ ). ${ }^{\mathrm{a}} \mathrm{p}<0.001$ and ${ }^{\mathrm{b}} \mathrm{p}<0.05$ vs control, ${ }^{\mathrm{c}} \mathrm{p}<0.001$ vs CP group, ${ }^{\mathrm{d}} \mathrm{p}<0.001$ vs CP+LLLT group and ${ }^{\mathrm{e}} \mathrm{p}<0.001$ vs LLLT group.
When the $\mathrm{CP}+\mathrm{ACA}$ group and the $\mathrm{CP}$ group were compared, apoptosis levels were significantly decreased in the $\mathrm{CP}+\mathrm{ACA}$ group $(\mathrm{p}<0.001)$. In the LLLT group, however, the level of apoptosis was found to be significantly increased compared to the control group $(\mathrm{p}<0.001)$. The levels of apoptosis were significantly higher in the $\mathrm{CP}+$ LLLT groups compared to the CP group ( $<<0.001)$ (Fig. 5).

\section{Discussion}

One of the most commonly used chemotherapy protocols is CP, an alkylating agent especially used in metastatic colon cancers. It is well known that there is a significant relationship between the efficacy of $\mathrm{CP}$ and plasma concentrations. However, cardiac side effects are the most important conditions that partially restrict the use of CP (14). Many recent studies have shown abnormal TRP channel expression in various cancer types. In several studies, the effects of subtypes of TRP channels on many different cancer cells and the relationship between TRP channel expression and surveillance in these cancers have been clearly demonstrated (15). TRP channels have also been reported to be capable of responding to the physicochemical signals of metastatic cells in cancer cells and played an important role in metastatic cascade (16). TRPM channels have been reported to play a role in PH balance (TRPM 2,7,8), cytokine (TRPM 2,4) and ROS release (TRPM 2,4,7), adhesion (TRPM7) and invasion (TRPM8) in tumour cells. Furthermore, TRPM2 channels had a role in maintaining the continuity of the endothelial barrier and activation of these channels with oxidants resulted in extravasation and intravasation $(15,17)$.

It is well known that intracellular $\mathrm{Ca}^{2+}$ levels have important effects on cancer cells and TRP channels, and that they play significant roles in oxidative stress and apoptosis. It has been reported that stimulation of TRP channels disrupted ionic haemostasis in the cell and caused intracellular calcium entry leading to cell death (18). Enhanced $\mathrm{Ca}^{2+}$ levels results in an increase in the amount of

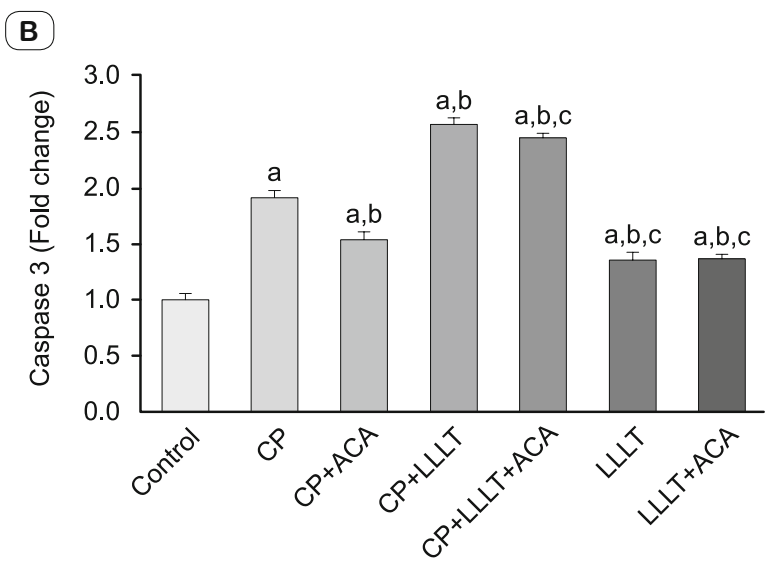

Fig. 4B. The effect of Cyclophosphamide (CP, $50 \mathrm{mM}, 24 \mathrm{hrs)}$ and LLLT $(808 \mathrm{~nm}, 30 \mathrm{Joule} / \mathrm{cm} 2)$ on caspase 3 levels in the Caco-2 Cells. Cells are stimulated by Cumene hydroperoxyde (Cpx, $0.1 \mathrm{mM}$ for 10 min) but they were inhibited by Antranilic acid (ACA, 0.1 mM, 30 min) (mean \pm SD and $n=10)$. ${ }^{a} \mathbf{p}<0.001$ vs control, ${ }^{b} \mathbf{p}<0.001$ vs $\mathrm{CP}$ group, ${ }^{c} p<0.001$ vs $C P+L L L T$ group and ${ }^{d} p<0.001$ vs LLLT group. 


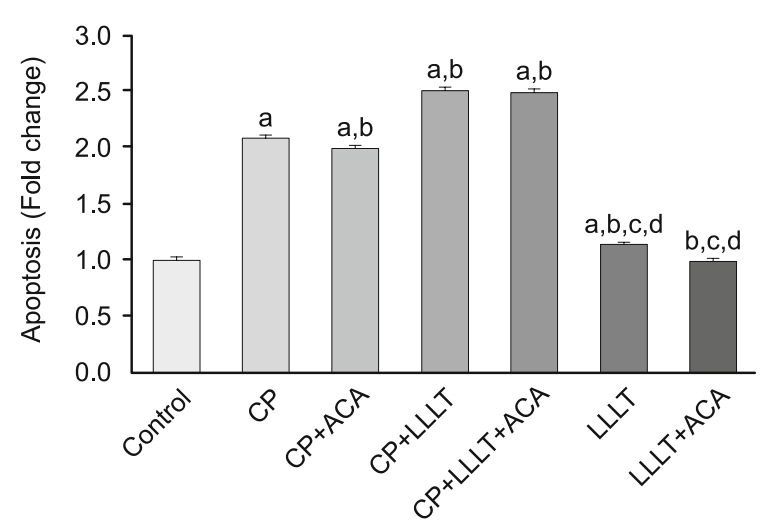

Fig. 5. The effect of Cyclophosphamide (CP, $50 \mathrm{mM}, 24 \mathrm{hrs})$ and LLLT $\left(808 \mathrm{~nm}, 30 \mathrm{Joule} / \mathrm{cm}^{2}\right)$ on apoptosis levels in the Caco-2 Cells. Cells are stimulated by Cumene hydroperoxyde (Cpx, $0.1 \mathrm{mM}$ for $10 \mathrm{~min}$ ) but they were inhibited by Antranilic acid (ACA, $0.1 \mathrm{mM}, 30 \mathrm{~min}$ ) (mean \pm SD and $n=10$ ). ${ }^{a} \mathbf{p}<0.001$ vs control, ${ }^{b} \mathbf{p}<0.001$ vs $\mathrm{CP}$ group, ${ }^{c} \mathbf{p}<0.001$ vs CP+LLLT group and ${ }^{d} \mathbf{p}<0.001$ vs LLLT group.

ROS, inducing oxidative stress triggered by mitochondrial membrane depolarization and as the result, apoptosis occurs through caspase 3 and caspase 9 activation (19). There are limited number of studies in literature examining the effects of chemotherapeutic agents on TRP channels. It is known that chemotherapeutic agents increase intracellular $\mathrm{Ca}^{2+}$ levels by free oxygen radicals in the cell and result in oxidative stress. Recent studies have shown that there was a close and strong correlation between TRP channel expression and survival rates emphasizing that TRP channels can be used as a pharmacological target. It has been reported that targeting of TRP channels could aim at tumours, stroma and immune cells with the use of a single drug and this might provide an important advantages such as at least a partial effect on chemotherapy resistance cells by TRP channel inhibition (15). In our previous study, we demonstrated that, TRPM2 channels expression was significantly increased in both colon and breast cancer and TRPM2 channels expression was directly related to apoptotic effects of 5-flourouracil/leucoverin combination treatment in this cancer cells (20). In this study, we investigated the role of CP in the treatment of CP and found that during chemotherapeutic agent use, there was a significant increase in apoptosis levels in cancer cells by TRPM2 channel activation and a significant decrease by TRPM2 channel inhibition compared to the control group.

LLLT, which is used clinically for the treatment of many diseases, has a wavelength of $600-1,100 \mathrm{~nm}$, an output power of $1-500 \mathrm{~mW}$ and a relatively lower energy density $\left(0.04-50 \mathrm{j} / \mathrm{cm}^{2}\right)$. LLLT prevents cell apoptosis in low-level rays and may increase cell proliferation and migration (21). The biomodulatory effect of LLLT varies from cellular proliferation to programmed cell death. LLLT has been reported to modify the effectiveness of biphasic dose and wavelength (22). It is believed that the effect of LLLT increases ATP production and its bioinhibitor effect is associated with oxidative stress arising from the overload of ROS (23). In our study, there was a significant increase in apoptosis levels in cancer cells with TRPM2 channel activation compared to the control group with the use of LLLT, while a statistically significant decrease in apoptosis levels occurred as th result of TRPM2 channel inhibition. Furthermore, it was found that LLLT increased apoptotic efficacy of CP, this effect increased with TRPM2 channel stimulation and decreased with a channel inhibition.

Different results have been obtained in the studies investigating the efficacy of LLLT on the treatment of various types of cancer. In the study similar to ours, it was concluded that LLLT increased cell death in breast cancer cells (7). In the study performed on the oral squamous cell line, LLLT was found to reduce cancer cell development (24). In another study investigating the efficacy of LLLT in head and neck cancers, it was reported that LLLT induced tumour development (25). In another study examining the efficacy of LLLT in laryngeal cancers, an increase in the number of cancer cells was reported in a high-energy application (26). Furthermore, the study on lung cancer cells emphasized that LLLT should be avoided in treatment because it accelerates tumour proliferation (8).

In conclusion, the apoptotic effects of $\mathrm{CP}$ on tumour cells were directly related to TRPM2 channels following CP and LLLT treatment, separately or alone, in colon cancer. It has been found that LLLT application increased apoptosis in colon cancer cells and these effects were associated with TRPM2 channels and combined application of LLLT and CP increased apoptotic effect of CP.

\section{References}

1. Kim JH. Chemotherapy for colorectal cancer in the elderly. World J Gastroenterol 2015; 21 (17): 5158-5166.

2. Ma B, Zhang Y, Gu L et al. Comparative pharmacokinetics of cyclophosphamide administration alone and combination with vitamin B6 in rats. Biomed Chromatogr 2015; 29 (1): 62-67.

3. Scurr M, Pembroke T, Bloom A et al. Low Dose Cyclophosphamide Induces Antitumor T-Cell Responses, which Associate with Survival in Metastatic Colorectal Cancer. Clin Cancer Res 2017; 23 (22): 6771-6780

4. Nishida M , Kuwahara K, Kozai D, Sakaguchi R, Mori Y. TRP Channels: Their Function and Potentiality as Drug Targets. Innovative Medicine 2015.

5. Toledoa AS, Espinoza-Gabriela MI, Condadoc DM. Evaluation of the TRPM2 channel as a biomarker inbreast cancer using public databases analysis Bol Med Hosp Infant Mex 2016; 73 (6): 397-404.

6. Park YR, Chun JN, So I et al. Data-driven analysis of TRP channels in cancer: linking variation ingene expression to clinical significance. Cancer Genomics Pro-teomics 2016; 13: 83-90.

7. Jafarirad S, Hammami Torghabe E, Rasta SH, Salehi R. A novel non-invasive strategy for low-level laser-induced cancer therapy by using new $\mathrm{Ag} / \mathrm{ZnO}$ and $\mathrm{Nd} / \mathrm{ZnO}$ functionalized reduced graphene oxide nanocomposites. Artif Cells Nanomed Biotechnol 2018; 15: 1-17.

8. Kara C, Selamet H, Gökmenoğlu C, Kara N. Low level laser therapy induces increased viability and proliferation in isolated cancer cells. Cell Prolif 2018; 51 (2): e12417.

9. AIGhamdi KM, Kumar A, Moussa NA. Low-level laser therapy: A useful technique for enhancing the proliferation of various cultured cells. Lasers Med Sci 2012; 27: 237-249. 
10. Singh N, Nigam M, Ranjan V et al. Resveratrol as an adjunct therapy in cyclophosphamide-treated MCF-7 cells and breast tumor explants. Cancer Sci 2011; 102 (5): 1059-1067.

11. Martinez NA, Ayala AM, Martinez M, Martinez-Rivera FJ, Miranda JD, Silva WI. Caveolin-1 Regulates the P2Y2 Receptor Signaling in Human 1321N1 Astrocytoma Cells. J Biol Chem 2016; 291 (23): 12208-12222.

12. Öz A, Çelik Ö. Curcumin inhibits oxidative stress-induced TRPM2 channel activation, calcium ion entry and apoptosis values in SH-SY5Y neuroblastoma cells: Involvement of transfection procedure. Mol Membr Biol 2016; 33 (3-5): 76-88.

13. Yiğit M, Güneş A, Uğuz C et al. Effects of astaxanthin on antioxidant parameters in ARPE-19 cells on oxidative stress model. Int J Ophthalmol 2019; 12 (6): 930-935.

14. Ayash LJ, Wright JE, Tretyakov O et al. Cyclophosphamide pharmacokinetics: correlation with cardiac toxicity and tumor response. J Clin Oncol 1992; 10: 995-1000.

15. Fels B, Bulk E, Petho Z, Schwab A. The Role of TRP Channels in the Metastatic Cascade. Pharmaceuticals 2018; 11 (2): 48-73.

16. Riggi N, Aguet M, Stamenkovic I. Cancer Metastasis: A Reappraisal of Its Underlying Mechanisms and Their Relevance to Treatment. Annu Rev Pathol 2018; 13: 117-140.

17. Mittal M, Nepal S, Tsukasaki Y et al. Neutrophil Activation of Endothelial Cell-Expressed TRPM2 Mediates Transendothelial Neutrophil Migration and Vascular Injury. Circ Res 2017; 121: 1081-1091.

18. Boonstra MC, de Geus SW, Prevoo HA et al. Selecting Targets for Tumor Imaging: An Overview of Cancer-Associated Membrane Proteins. Biomark. Cancer 2016; 8: 119-133.
19. Uğuz AC, Naziroğlu M, Espino J et al. Selenium modulates oxidative stress-induced cell apoptosis in human myeloid HL-60 cells through regulation of calcium release and caspase-3 and -9 activities. J Membr Biol 2009; 232 (1-3): 15-23.

20. Guler Y, Ovey IS. Synergic and comparative effect of 5-fl uorouracil and leucoverin on breast and colon cancer cells through TRPM2 channels. Bratisl Med J 2018; 119 (11): 692-700.

21. Al Ghamdi KM, Kumar A, Moussa NA. Low-level laser therapy: a useful technique for enhancing the proliferation of various cultured cells. LasersMed Sci 2012; 27: 237-249.

22. Kiro NE, Hamblin MR, Abrahamse H. Photobiomodulation of breast and cervical cancer stem cells using low-intensity laser irradiation Tumour Biol 2017; 39 (6); 1010428317706913.

23. Kim HP. Lightening up light therapy: activation of retrograde signaling pathway by photobiomodulation. Biomol Ther 2014; 22 (6): 491-496.

24. Schartinger VH, Galvan O, Riechelmann H, Dudas J. Differential responses of fibroblasts, non-neoplastic epithelial cells, and oral carcinoma cells to low-level laser therapy. Support Care Cancer 2012; 20: $523-529$.

25. Sperandio FF, Giudice FS, Correa L Pinto DS Jr, Hamblin MR, de Sousa SC. Low-level laser therapy can produce increased aggressiveness of dysplastic and oral cancer cell lines by modulation of Akt/mTOR signaling pathway. J Biophotonics 2013; 6: 839-847.

26. Kreisler M, Christoffers AB, Willershausen B, D'Hoedt B. Low level $809 \mathrm{~nm}$ GaAlAs laser irradiation increases the proliferation rate of human laryngeal carcinoma cells in vitro. Lasers Med Sci 2003; 18 : $100-103$. 